\title{
Lexical analysis of the Code of Medical Ethics of the Federal Council of Medicine
}

\author{
Edson de Oliveira Andrade JR. ${ }^{1}$, Edson de Oliveira Andrade ${ }^{2 *}$ \\ ${ }^{1}$ Fundação de Medicina Tropical Doutor Heitor Vieira Dourado, Pediatrics, Manaus, Amazonas, AM, Brazil \\ ${ }^{2}$ Universidade Federal do Amazonas, Faculdade de Medicina, Internal Medicine, Manaus, AM, Brazil
}

Study conducted at Universidade Federal do Amazonas, Faculdade de Medicina, Clínica Médica, Manaus, AM, Brazil

Article received: $1 / 18 / 2016$ Accepted for publication: 1/27/2016

*Correspondence: Address: Universidade Federa do Amazonas - Faculdade de

Medicina, Clínica Médica

Av. Apurinã, 1053, Praça 14 Manaus, AM - Brazi

Postal code: 69020-160 dredsonandrade@gmail.com

http://dx.doi.org/10.1590/1806-9282.62.02.123

\section{SUMmARY}

Introduction: The Code of Medical Ethics (CME) of the Federal Council of Medicine is the legal document that exposes the moral discourse of Brazilian physicians to society and the profession. It is a set of propositions based on which doctors say they are committed to values of conduct aimed at fair and proper professional practice.

Objectives: To verify through lexical analysis of the CME corpus if the goals presented in the arguments of the resolution that established the code are properly addressed in these regulations.

Methods: This is a quantitative and qualitative study of descriptive nature, aiming at a lexical analysis of the CME. The lexical analysis was performed using a method of Top-Down Hierarchical Classification of vocabulary, as described by Reinert in 1987, assuming that words used in similar contexts are associated with a single lexical world. In addition to the analysis of results, an improved representation of the charts related with Factorial and Similitude Analyses was made.

Results: Six clusters were extracted, leading to the identification of three major branches: health care, professional practice and research. These branches revolve around the figures of physician and patient. The similitude analysis revealed a complementarity status between these two figures.

Conclusion: The lexical analysis showed that the purposes contained in the resolution that established the CME were adequately represented in the document body.

Keywords: medical ethics, code of ethics, lexical analysis, Iramuteq.

\section{INTRODUCTION}

A code of professional ethics constitutes the moral discourse of a profession in face of society. This is how a professional category positions itself regarding the rights and responsibilities that should be observed for proper practice, so that the objectives of that specific craft can be achieved.

The Code of Medical Ethics $(\mathrm{CME})^{1}$ of the Federal Council of Medicine that is currently in force was established by the Federal Council of Medicine (CFM, Conselho Federal de Medicina) resolution no. 1931/2009, and states the following:

WHEREAS the Councils of Medicine are simultaneously judges and discipliners of the medical class, with a responsibility to ensure and work, by all means in their power, to promote the perfect ethical practice of Medicine, as well as the prestige and good reputation of those legally practicing the profession;

$[\ldots]$

CONSIDERING the search of a better relationship with the patient, guaranteeing greater personal autonomy according to his or her will;

CONSIDERING the proposals made over the years 2008 and 2009 by the Regional Councils of Medicine, Medical Entities, physicians, research entities and universities to review the current Code of Medical Ethics;

CONSIDERING the decisions made at the $4^{\text {th }}$ National Conference of Medical Ethics that drafted a new reviewed Code 
of Medical Ethics with the participation of representative physicians from all over Brazil.

Thus, some fundamental features in this normative document can be identified: the defense of the perfect ethical practice of medicine; the patient as the primary object of the document; and the democratic character of its construction, characterized by extensive consultation at the time of its preparation.

The manner in which the CME was drafted is not the subject of this study, although this would further reinforce the idea that these norms represent the ethical and moral discourse of the profession to society. This is not a document that was imposed or declared, but a document that was built over time and upon reflection of medical professionals throughout the country. The discourse delivered, the substance, is what interests us.

But does the discourse really express such commitment to the patient? How is it possible to answer this question based on the analysis of twenty-five fundamental principles and one hundred and eighteen articles? In order to answer these questions, the authors choose to perform a discourse (CME) analysis using lexical analysis followed by text content analysis.

This study aimed to verify the consistency between what was promised in the resolution that established the CME and what is written in the norm. Paraphrasing Chico Buarque in a song entitled "Fado tropical", to verify if there is distance between intention and gesture. ${ }^{2}$

\section{THEORETICAL BACKGROUND}

\section{History of the Brazilian codes of medical ethics ${ }^{3}$}

According to the Federal Council of Medicine, in the history of Brazilian medicine, there had been five codes of ethics officially acknowledged by physicians. The 2009 code is the sixth. Before these formal codes were in force, some initiatives promoted the development of the theme in Brazil.

- Translations - In 1867, the Medical Gazette of Bahia published a translation of the Code of the American Medical Association, largely influenced by the work of Thomas Percival.

- Over sixty years later, in 1929, the Brazilian Medical Association published the Medical Moral Code, a translation of the Medical Moral Code approved in the Fourth Latin American Medical Congress.

- The first Brazilian document - A code adapted to the Brazilian reality, with the participation of physicians and medical entities, began to be written during the $1^{\text {st }}$ Syndicalist Medical Congress of 1931, year in which the Code of Medical Deontology was approved, although without legal status.

- Codes acknowledged - The first code officially acknowledged in Brazil was the Code of Medical Deontology, approved in October 1944 at the Fourth Syndicalist Medical Congress.

In 1953, the Brazilian Medical Association (AMB, Associação Médica Brasileira) produces a Code of Medical Deontology that was later adopted by the Federal Council of Medicine and remodeled to become a regulatory authority and ethics court according to law no 3268/1957.

The Federal Council of Medicine then took on the task of voting and amending the Code of Medical Deontology. The work was consolidated in the Congress of Regional Medical Councils in 1963. In that year, the Code of Medical Ethics was published, being in force in January 1965 after a few modifications.

The 1965 Code was valid until 1984, when the Brazilian Code of Medical Deontology was established. The following code would appear in 1988 as part of the country's re-democratization process. The text was written during the First National Conference of Medical Ethics held on November 24-28, 1987 in Rio de Janeiro.

The current Code of Medical Ethics came into force on April 13, 2010. Revised more than 20 years after the previous code, it included novelties such as the prediction of palliative care, patient autonomy, and rules for assisted reproduction. The document comprised 25 fundamental principles of medical practice, 10 diceologic norms, 118 deontological norms, and four general dispositions.

\section{The discourse}

According to Orlandi, ${ }^{4}$ discourse is the dynamic expression of words aiming at intermediating men and their natural and social reality, which can, however, present itself with different faces and meanings. ${ }^{5}$ Foucault, ${ }^{6}$ in his lecture on The Order of Discourse, establishes that discourses are dispersed and it is a role of discourse analysis to seek the formation rules governing its construction in a given context.

But discourse is beyond grammar; it always has a speaker and a listener; it deals with concrete enunciations; it is contextualized and built on a network of other discourses.

Discourse manifests itself linguistically through texts. That is, discourse materializes in the form of texts. Therefore, it is by analyzing (the) text(s) that one can under- 
stand how a discourse functions. It is built in the process of interacting relationships, i.e., when a speaker interacts with another or with others by means of language. ${ }^{7}$

But would an ethics code be a kind of discourse?

Habermas, ${ }^{8}$ the great theoretician of "discourse ethics", considers that there is no distinction between the moral principle and the discursive principle, since the latter is grounded on symmetric conditions of recognition of life forms communicatively structured.

According to him, in moral discourses, the discursive principle takes on a character of universalization, where moral becomes a rule of argument.

The philosopher proposes that, in communicative actions, the legitimate right only harmonizes with a type of legal coercion that guarantees the right of the recipient to obey it or not.

In general, in order for a discourse to be valid, including the moral discourse contained in the CME, some principles are to be met, which he calls "validity expectations" (Geltungsansprüche), namely: a) understanding of the content; b) true interlocutors; c) true contents; d) valid reasons to express the discourse. If any of these assumptions is disturbed, the discourse, and in this case the code, can be challenged to its core. The problematized statement should be discussed in a theoretical discourse; and the norm, problematized in a practical discourse. ${ }^{9}$

The manner in which the CME was built as a moral discourse, based on a legitimate motivation characterized by the need for social protection, and with clear writing and valid content, all seem to meet the philosopher's precautions.

It is acceptable to say, for perfect clarification, that for Habermas the difference between ethics and moral is that the first fits into a first-person perspective, of who one is and who one wants to become later in life, while the latter deals with what should or should not be done regarding others with the purpose of treating them as free and rational beings who deserve respect. For Habermas, moral has priority and functions as a limit for ethics: I have to plan what is good or valuable to me (ethical dimension) without running over what is right or fair to the other (moral dimension). This is how a professional code of ethics, properly constructed, should be.

According to Nunes Junior, ${ }^{10}$ in terms of rights, the brilliance in Habermas' theory is in

replacing a practical reason (act guided by one's own ends) with a communicative reason, an individual who, using his or her own judgment, reaches a norm through communicative rationality based on a group that guides its own ac- tion by discursive procedures, also reaching the norm. Thus, the reasoning of the Law, its measure of legitimacy, is defined by the logic of the best argument. As emanation of the discursive will of free and equal citizens, the Law is able to accomplish the great aspiration of reality, that is, the realization of justice.

According to Godoi, ${ }^{11}$ "the communicative rationality proposed by Habermas differs substantially from the practical rationality, previously supported by the philosophy of law or the philosophy of history. While the practical rationality sought to be a source of prescriptions for the social role of the individual, or even the State, communicative rationality seeks only to define the procedural conditions of the discourse in which social subjects can reach a legitimate understanding that generates social integration and shared expectations" (1999, p. 67). As it was written in a plural form, the CME also seems to meet the communicative rationality proposed by Habermas.

\section{Normative discourse}

The normative discourse is that of the legislator, an agent invested with competence and power to carry out a social task, in this case the regulation of conducts. It is the alleged reason for study of the other types of discourse. The legislator performs its discursive paper addressing the community that receives the texts it created. ${ }^{12}$

According to Eduardo Bittar, ${ }^{12,13}$ the norm, its creation, is a state of relationship between two subjects aiming at something of value. It is a discourse constructed with arguments, defense, dissent and consensuses.

Thus, as stated by Edvaldo Brito, ${ }^{14}$ the rule of law should not be addressed solely as a prescriptive proposition. It should include the analysis of figures such as the enunciator (emitter), and be regarded as a communicative phenomenon assessing emitter- receptor-emitter relations, thus fitting into Habermas' "communicative action".

Eduardo Bittar ${ }^{13}$ points out the importance of the adjuvants, that is, external influences to normative discourse, such as social political and cultural pressure. The opponent is also under the spotlight, which is the resistance offered by the legal statute itself, in the case of the CME, represented by ethics to be replaced.

It is important to say that the normative text represents security for those submitted to it as subjects. Nevertheless, he finds that an excessive amount of texts means hypertrophy of the system, which ultimately leads to malfunction, and causes a problem of legal uncertainty as conflict arises among the many texts. It is true that the system ends up solving these contradictions using self- 
correcting mechanisms, as in the case of a special law that prevails over a general rule, or a supervening law that overrules the previous, etc.

Last, Bittar warns that normative emanations do not necessarily respond to the factual claims, and there is a "huge gap between the sense idealized in a norm and the sense achieved as social practice". ${ }^{13}$ Such concern is a posteriori of this study's subject matter, which seeks to understand if the motivators expressed in the CME are effectively contained there. If they are not, there will be an impediment of the code's effect in the social practice.

\section{The norm of ethics}

Ethics norms are a kind of cultural norm. Their purpose is not to understand or explain cultural phenomena but to determine or control them in the sense of allowing value realization.

Considering that the norms of ethics arise in cultural societies, their objective is to specify human behaviors that are allowed, prohibited or mandatory, limiting the possibilities of transformation or the existence of facts to those allowing the realization of social values.

Some human behaviors can result in socially undesirable situations and are, therefore, prohibited by ethics norms; conversely, other behaviors may be indispensable for the realization of social values, which makes them mandatory.

Even though there are ethics norms of many kinds, including legal, religious and social norms, one can say that they all have common features, such as: authoritativeness (indicative of social normality - "what should be"), violability (possibility of breaking the norm, which is therefore followed by sanction) and counterfactuality (the ethical norm should not submit to the facts, but the opposite).

Bentham's theory of "ethical minimum", apud Reale, ${ }^{15}$ consists in saying that the law represents only the moral minimum declared as mandatory so that society can subsist. Since not everyone can or want to comply spontaneously with moral obligations, it is essential to strengthen certain ethical principles, so that society does not perish.

\section{Methods}

This is a quantitative and qualitative descriptive study aimed at performing a lexical analysis of the code of medical ethics of the Brazilian Federal Council of Medicine.

Lexical analysis was conducted using a method of Top-Down Hierarchical Classification of vocabulary, as described by Reinert, assuming that words used in simi- lar contexts are associated with a single lexical world. ${ }^{16}$ The criterion for including elements in their respective classes is a higher frequency compared to the average occurrence in the corpus, as well as an association with the class determined by chi-square value equal to or higher than 3.84. This gives an error margin $<.05$ (for a liberty degree $=1$ ).

In order to achieve that, the authors used Iramuteq (Interface de R pour analyses Multidimensionnelles de Textes et de Questionneires) software, ${ }^{17}$ specific for text analysis accross large corpora, complementing the assessment of results with enhanced representation of graphs related to Factorial and Similitude Analyses. ${ }^{18,19}$

\section{Hypothesis}

- H0: The CME text corpus is concordant with the considerations found in CFM Resolution no. 1931/2009.

- H1: The CME text corpus is in disagreement with the considerations found in CFM Resolution no. 1931/2009.

\section{Data analysis}

The text corpus gathered from the CME was subjected to Top-Down Hierarchical Classification (DHC) using Iramuteq software, which performed quantitative analyses of textual data providing contexts and classes of the contents based on vocabulary similarity.

Factor analysis performed by the software allows us to describe the main components of CME, focusing on the occurrence in the norm's text of the most common subjects, verbs and adjectives. This technique enables the identification of the number of clusters in the text. Here, cluster is defined as a set of words that tend to appear close to one another in the text, forming a specific segment. Based on these clusters, central points of the text can be pointed out, as well as how the terms are associated with one another.

These classes or clusters represent the environment of sense of the words, and can indicate social representations or elements of social representations concerning the social object under study. ${ }^{20}$

In addition, to identify co-occurrences and connectivity among words, a similarity analysis was performed (Iramuteq) based on the theory of graphs, which aids the identification of the representation structure.

\section{Results}

The CME has 4387 words; of these, 1241 are active or supplementary forms, and 962 occurrences of lemmatization. In the CME, the most repeated nouns or subjects were 
"physician" and "patient", 90 and 75 times, respectively. The verb most used was "let", 44 times, followed by "should/ must" in 19 opportunities. The adjectives found more often were "professional" (39) and "legal" (21).

Factorial analysis (FCA) identified six clusters or classes of words as a whole. The test also indicates the degree of statistical significance of the words that occur most often in each cluster. The presence of statistical significance indicates that certain terms tended to appear in a certain cluster, while the lack of significance shows that the terms were present in several groups. Therefore, the higher the significance of the presence of a certain term, more specific it is in that group. Figure 1 below shows the composition of each cluster to describe the sets within the discourse. The largest cluster is in class 4, representing $20.8 \%$ of the discourse. Following is class 1 , with $19.6 \%$, and class 5 , with $17.8 \%$. The remaining classes make up less than $15 \%$ of the discourse each. Classes 1 and 2 derive from the same branch and, therefore, tend to pres- ent greater connection with each other. The same is true for the other branch, which includes classes 3 and 4.

The analysis of clusters 1 and 2 (34.6\%) demonstrates that they report physician and patient autonomy in a process of shared decision concerning care to be delivered; due respect to the confidentiality of the information received; as well as the physician's obligation to always use the best of medical science for the benefit of his/her patient.

Respect for patient autonomy is one of the main advances of the CME. This is a change in the Hippocratic paradigm of paternalism of the doctor-patient relationship. A study conducted at Hospital das Clínicas, University of São Paulo, revealed that $86 \%$ of the female and $76.6 \%$ of the male patients would like to have active participation in the therapeutic decisions to be made. ${ }^{21}$ The results above were obtained before the launching of the new CME, and the full inclusion of this matter in the normative body of the code demonstrates that legislators were aware of this demand.

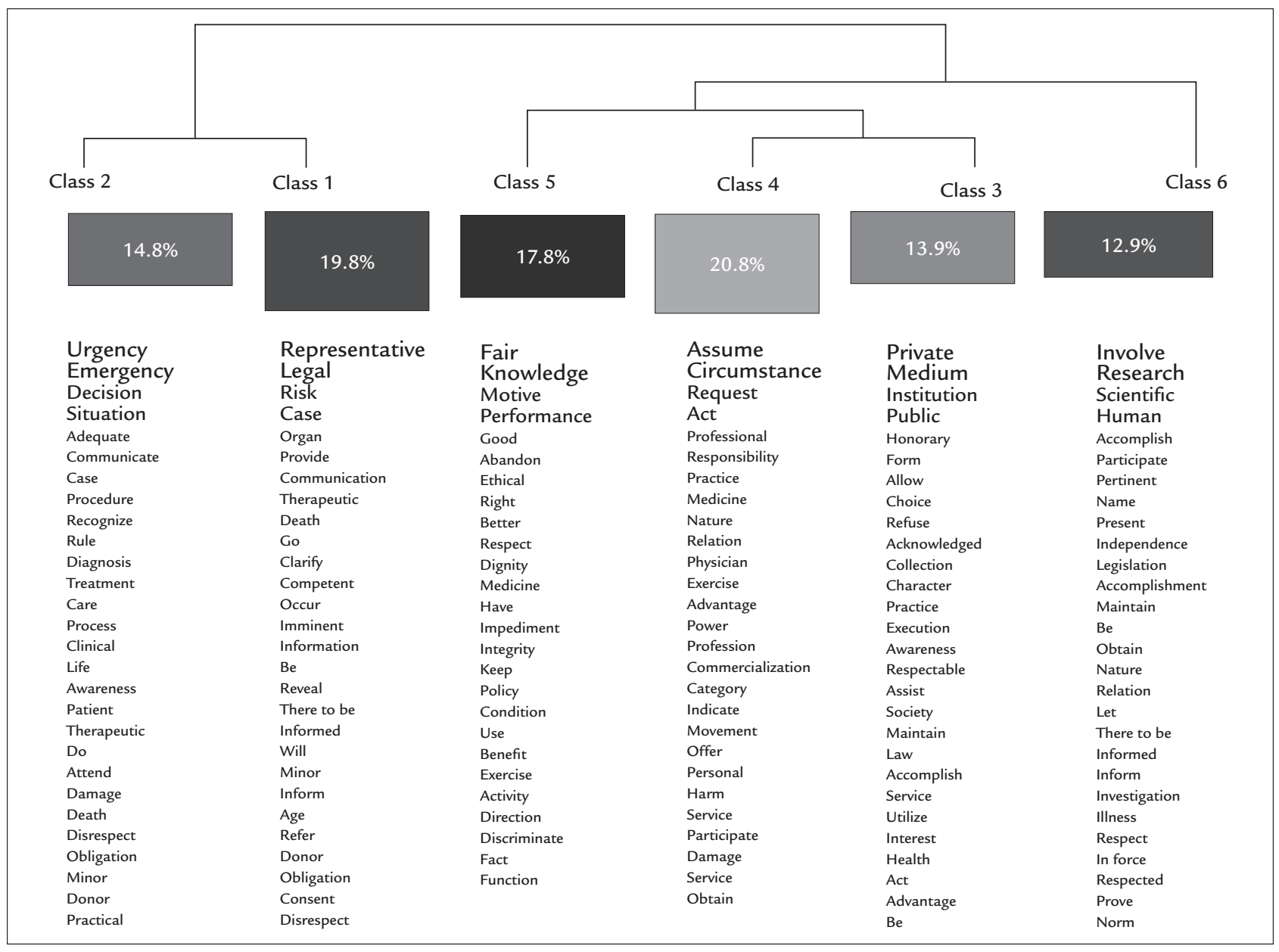

FIGURE 1 Dendogram of top-down hierarchical classification of the "Code of Medical Ethics" corpus. 
Clusters 3, 4 and 5 (42.5\%) refer to professional behavior regarding market relations in the practice exercised in both public and private spaces. They contain the rights and duties arising out of the profession in interactions beyond the doctor-patient relationship, despite being a result of or affecting this relationship. They also contain the formal obligations to the Council of Medicine.

Cluster 6 is one that appeared more isolated in the factor extraction process. It expresses a class of obligations aimed at medical research that often occur in the context of health care, imposing a very specific character that sets it apart from other classes.

Thus, using a factorial analysis of components (Figure 2), it is possible to divide the discourse of the CME into three major branches: health care, professional practice and research. These branches revolve around the figures of doctor and patient.

To view the representation structure in the CME and confirm the centrality of elements, a co-occurrence analysis was made based on categories developed from each word evoked. ${ }^{22}$ Therefore, a similitude analysis was applied, allowing the connection among elements of the representation to be viewed, as shown in Figure 3. Lon- ger words in bold demonstrate their relevance for the connection of elements - the longer the word, the higher the frequency and contribution to form connection trees. ${ }^{23}$

As we can see in the similarity tree, the CME is divided into two poles: physician and patient; each with an array of attributes, duties and competences to characterize them.

\section{Discussion}

The question of characterization of a normative discourse, subject to lexical or content analysis, is something that discourse theorists state as possible. ${ }^{6-8,12,24,25}$ The search for the validity of this discourse ${ }^{9}$ prompts a brief comment on the form and the mechanisms used in its preparation. The CME constitutes a normative and moral discourse. ${ }^{24}$ Precepts described as valid, whether logical-semantic or ethical, were apparently observed when the document was drafted. Of these, broad and democratic manner in which the norm was written is noted. Consultation of society was quite extensive, beyond corporate boundaries, which is reflected in the importance given to the autonomy of the patient in the doctrinal corpus.

The regulatory and supervisory character of the Council of Medicine is represented in the discourse analyzed

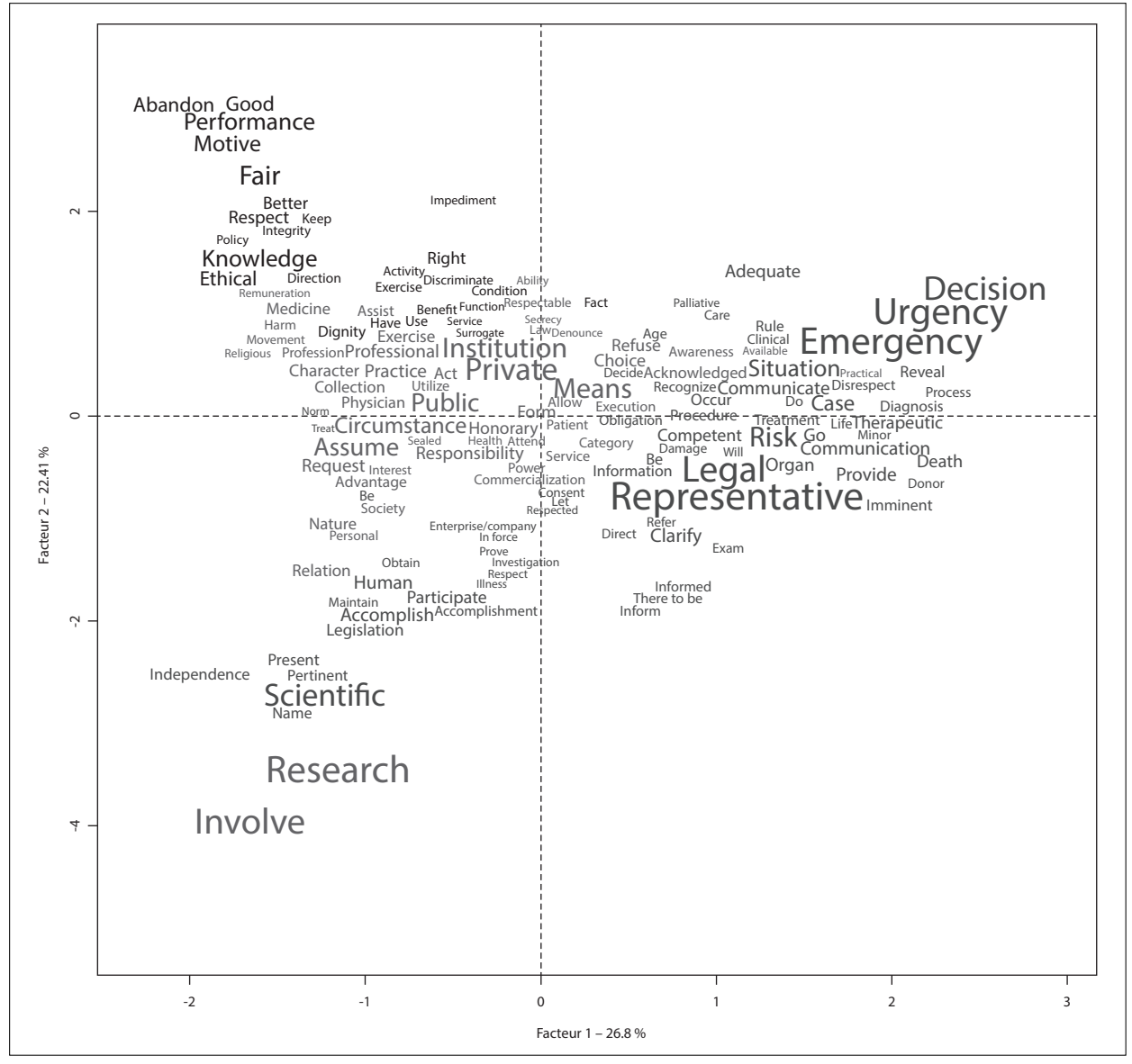

FIGURE 2 Factorial plan of the most significant words in the CME. 


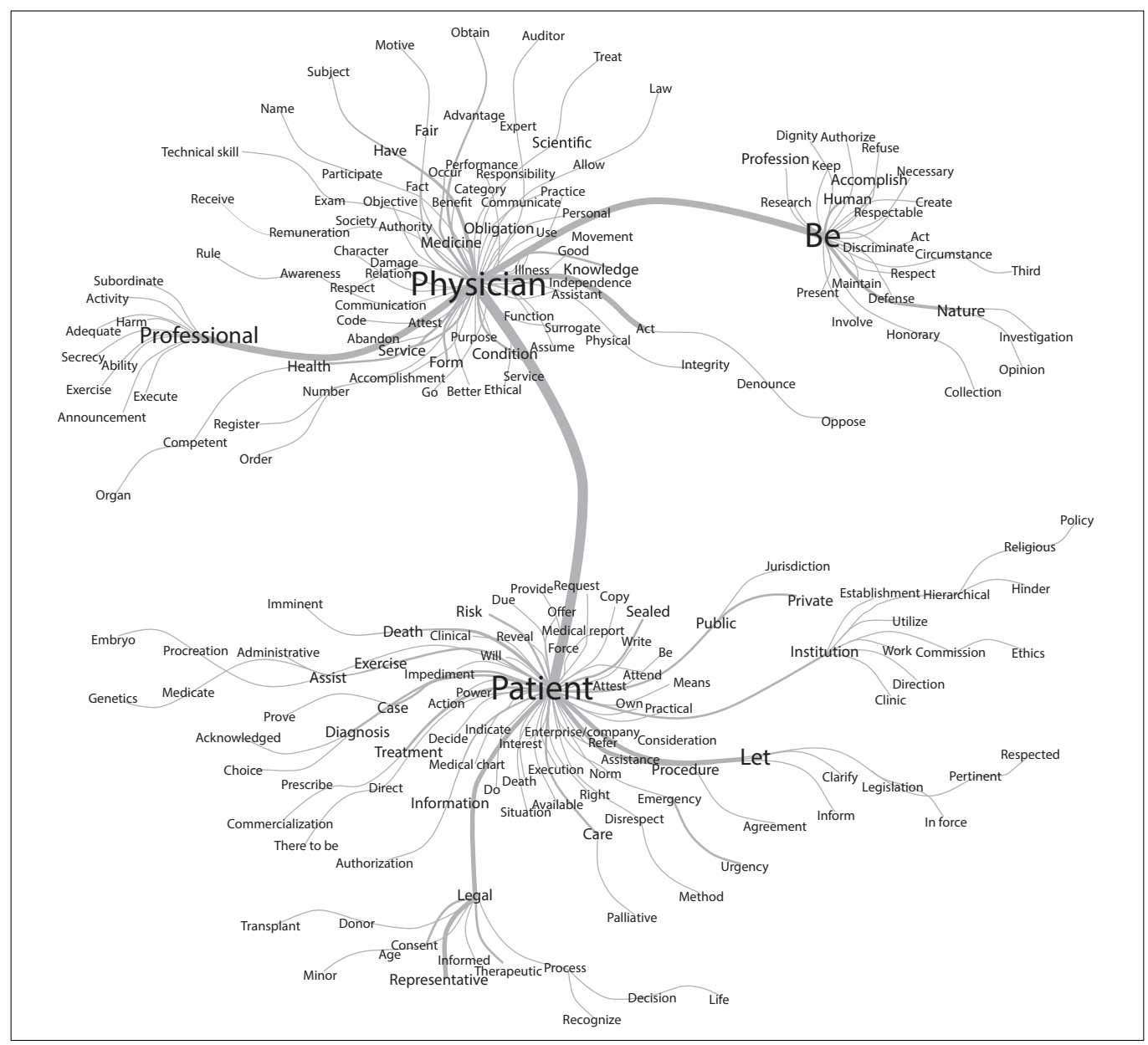

FIGURE 3 Maximum similitude tree.

in our study by what we call the legis-professional branch, included in the branch of professional practice. That's where the most formal and bureaucratic requirements are concentrated. It is the jurisdictional face of the discourse.

The attention given to modern concerns about the role of medical research for professional practice explains the importance of the issue in the CME. This class of moral obligations represents a concern that is more and more frequent in medical practice due to the increasing relevance of trials within the context of medical care. The absorption by the CME of the normative content of CFM resolution $\mathrm{n}^{\circ} 1885 / 2008$ was the consolidation of a position contrary to the Declaration of Helsinki developed by the World Medical Association regarding the use of placebo in scientific experiments if there is any effective treatment to be compared with the new drug that is being tested. ${ }^{26,27}$

Finally, we need to reflect on what the similarity tree shows. There seems to be two opposite poles in the CME discourse: On one side stands the physician and, on the other, the patient.

To be an ethical physician is to be professional. To be a patient is to be cared for, respected and protected.

The expressions used in the discourse are not isolated or autonomous, quite the contrary, since discourse is only realized through the relation between these poles. The figure does not display antagonism, but complementarity, indicating the existence of a dialogical unit represented by the doctor-patient relationship.

\section{Conclusion}

The CME, as all norms, is a discourse of the normative genre. As such, it can be analyzed using various methods. Lexical analysis proved that the purposes contained in the preamble to the resolution of the Federal Council of Medicine were properly met in the text developed and launched by the entity. In the code, there is a declared intention to protect the best medical practice, and the patients submitted to it, by encouraging an ethical and com- 
petent professional practice. Whether this occurs in daily life, and the impact of the code, are causes for further studies. ${ }^{28}$

\section{Resumo}

Análise lexical do Código de Ética Médica do Conselho Federal de Medicina

Introdução: o Código de Ética Médica do Conselho Federal de Medicina (CEM) é o documento normativo que expõe o discurso moral dos médicos brasileiros para a sociedade e a profissão. Ele constitui um conjunto de proposições a partir do qual os médicos dizem que se comprometem com valores de condutas visando a uma justa e correta prática profissional.

Objetivo: verificar através da análise lexical do corpus do CEM se os propósitos constantes nos considerandos da resolução que o instituiu estão devidamente contemplados nos normativos nele contido.

Método: estudo quanti e qualitativo de caráter descritivo que realiza uma análise léxica do CEM. A análise léxica foi efetuada pelo método de Classificação Hierárquica Descendente do vocabulário, descrito por Reinert (1987), assumindo que as palavras usadas em contexto similares estão associadas a um mesmo mundo lexical. Associada à análise de resultados com representação aprimorada dos gráficos referentes às análises fatoriais e de similitude.

Resultados: foram extraídos seis clusters, a partir dos quais foram identificados três grandes ramos: o assistencial, o profissional e o pesquisador. Todos giram em torno das figuras do médico e do paciente. A análise de similitude mostrou o estado de complementaridade das figuras do médico e do paciente.

Conclusão: a análise lexical mostrou que os propósitos contidos na resolução que instituiu o CEM foram adequadamente representados em seu corpo normativo.

Palavras-chave: ética médica, código de ética, análise lexical, Iramuteq.

\section{RefEREnCES}

1. Res. CFM n. 1931/2009 - Código de Ética Médica. Conselho Federal de Medicina do Brasil, 2009.

2. Buarque de Holanda F. Calabar [record]. Rio de Janeiro: Philips, 1973. Track 7, Fado Tropical.

3. Conselho Federal de Medicina. Breve histórico do Código de Ética Médica. 2010 [cited 2015 Dec 12]. Available from: http://www.portalmedico.org.br/ novocodigo/comofoielaborado.asp.

4. Orlandi EP. Análise do discurso. Campinas: Pontes, 2009.

5. Maingueneau D. Novas tendências em análise do discurso. 3.ed. Campinas: Pontes, 1997.

6. Foucault M. A ordem do discurso. São Paulo: Loyola, 2015.

7. Brandão HHN. Análise do discurso: um itinerário histórico. In: Pereira HBC Atik MLG (eds.). Língua, literatura, cultura em diálogo. São Paulo: Ed. Mackenzie, 2003.

8. Habermas J. Direito e democracia. Entre a facticidade e a validade. Rio de Janeiro: Tempo Brasileiro, 1997.

9. Habermas J. Consciência moral e o agir comunicativo. Rio de Janeiro: Tempo Brasileiro, 1989

10. Nunes Junior AT. As modernas teorias da justiça. Revista de Informação Legislativa. 2002; 39(156):53-62.

11. Godoi MS. Justiça, igualdade e direito tributário. São Paulo: Dialética, 1999

12. Pessoa FMG. A realidade do direito como linguagem: o discurso jurídico e suas espécies. Evocati Revista. 2008; 36.

13. Bittar ECB. Linguagem jurídica. 6.ed. São Paulo: Saraiva, 2015.

14. Brito E. Limites da revisão constitucional. Porto Alegre: Fabris, 1993.

15. Reale M. Lições preliminares de direito. São Paulo: Saraiva, 2001.

16. Reinert M. Classification descendante hiérarchique et analyse lexicale par contexte: application au corpus des poésies d'Arthur Rimbaud. Bulletin de méthodologie sociologique. 1987; 13:53-90.

17. Marchand P, Ratinaud P. L'analyse de similitude appliquée aux corpus textueles: les primaires socialistes pour l'élection présidentielle française. JADT. 2012; 687-99.

18. Camargo BV, Justo AM. IRAMUTEQ: um software gratuito para análise de dados textuais. Temas Psicol. 2013; 21(2).

19. Camargo BV, Justo AM. Tutorial para uso do software de análise textual Iramuteq. 2015 [cited 2015 Mar 03]. Available from: http://www.iramuteq. org/documentation/fichiers/tutoriel-en-portugais.

20. Nascimento-Schulze CM, Camargo EV. Psicologia social, representações sociais e métodos. Temas em Psicologia. 2000; 8(3):287-99.

21. Gulinelli A, Aisawa RK, Konno SN, Morinaga CV, Costardi WL, Antonio $\mathrm{RO}$, et al. Desejo de informação e participação nas decisões terapêuticas em caso de doenças graves em pacientes atendidos em um hospital universitário. RAMB. 2004; 50(1):41-7.

22. Bardin L. Análise de conteúdo. São Paulo: Ed. 70, 2011.

23. Vergés P, Bouriche B. L'analyse des données par les graphes de similitude. Auxerre: Sciences Humaines; 2001.

24. Ferreira A. Normas éticas: caracteres gerais. 2011 [cited 2015 Dec 20] Available from: http://introducaoaodireito.info/wpid/?p=191.

25. Ferreira FGA. O discurso jurídico como discurso prático: aspectos do debate entre Robert Alexy e Jürgen Habermas. Revista da Faculdade de Direito de Campos. 2006; 9:85-101.

26. Resolução n. 1.885 - Veda ao médico participar de pesquisa envolvendo seres humanos utilizando placebo quando existir tratamento disponível eficaz já conhecido. Conselho Federal de Medicina, 2008.

27. Schlemper Junior BR. O placebo e a Declaração de Pachuca: letras mortas? Revista Bioética. 2014; 22(3):462-70.

28. Hetem LA, Aguiar RW. Repercussões do novo Código de Ética Médica na prática psiquiátrica. Revista de Psiquiatria do Rio Grande do Sul. 2010; $32: 67$. 